Jurnal Adat dan Budaya, Vol.1, No.1 Tahun 2019

ISSN: E-ISSN 2615-6156, P-ISSN: 2615-6113

Jurnal Homepage: https://ejournal.undiksha.ac.id/index.php/JABI/index

\title{
PENGARUH MODEL SAVI BERBASIS TRI HITA KARANA TERHADAP SIKAP EMPATI DAN KOMPETENSI PENGETAHUAN IPA KELAS V SD
}

\author{
I Putu Eka Markandya ${ }^{1}$, Ndara Tanggu Renda ${ }^{1}$, Luh Putu Putrini Mahadewi² \\ 1Jurusan Pendidikan Dasar, \\ 2Jurusan Ilmu Pendidikan Psikologi dan Bimbingan, FIP \\ Universitas Pendidikan Ganesha Singaraja, Indonesia \\ E-mail: putu.eka.markandya@undiksha.ac.id
}

\begin{abstract}
Abstrak
Penelitian ini bertujuan untuk mengetahui secara simultan pengaruh model pembelajaran Somatic Auditory VisualizationIntellectualy (SAVI) berbasis Tri Hita Karana terhadap Sikap Empati dan Kompetensi Pengetahuan IPA kelas V SD di Gugus IV Kecamatan Bangli Tahun Pelajaran 2018/2019. Penelitian ini merupakan penelitian eksperimen semu (quasi eksperimen) dengan rancangan non-equivalen post test only control group design. Populasi pada penelitian ini adalah seluruhkelas V SD di Gugus IV Kecamatan Bangli Tahun Pelajaran 2018/2019 yang berjumlah 139 orang. Pengambilan sampel dalam penelitian ini menggunakan random sampling. Sampel penelitian ini yaitu kelas V SD N 2 Kubu yang berjumlah 23 orang sebagai kelompok eksperimen dan kelas V SD N 3 Cempaga yang berjumlah 22 orang sebagai kelompok kontrol.Data yang dikumpulkan dalam penelitian ini adalah sikap empati dan kompetensi pengetahuan IPA. Instrumen yang digunakan yaitu kuesioner dan test pilihan ganda. Data yang dianalisis dengan statistik deskriptif dan MANOVA berbantuan SPSS 17.For widows. Hasil penelitian dikuatkan berdasarkan perhitungan uji MANOVA yang memperoleh hasil angka signifikansi ketiga hipotesis 0,00 yang berarti kurang dari $0,05(0,00<0,05)$. Hasil penelitian menunjukan tedapat perbedaan secara simultan model pembelajaran SAVI berbasis Tri Hita Karana terhadap sikap empati dan kompetensi pengetahuan IPA siswa dengan nilai signifikansi $0,00<0,05$ ). Berdasarkan pengujian hipotesis dapat disimpulkan bahwa secara simultan terdapat pengaruh yang signifikan model pembelajaran SAVI berbasis Tri Hita Karana terhadap sikap empati dan kompetensi pengetahuan IPA siswa.
\end{abstract}

Kata kunci: IPA, SAVI, sikap empati, THK.

\begin{abstract}
This study aimed to determine the effect of the Tri Hita Karana-based Somatic Auditory Visualization Intellectually (SAVI) learning model on the Empathy Attitude and IPA knowledge competency in V grade Elementary school in Gugus IV at Bangli Sub-district in Academic Year 2018/2019. This study is a quasi-experimental study with a nonequivalentpost-test only control group design.The population in this study were all class V elementary school in Gugus IV Bangli Sub-district in Academic Year 2018/2019 which amounted to 139 people. The sampling of this study was used cluster random sampling. The sample of this study was class V SD N $2 \mathrm{Kubu}$, amounting to 23 people as the experimental group and class V SD N 3 Cempaga which amounted to 22 people as the control group.The data was collected in empathy and IPA knowledge competency. The instruments were used questionnaire and multiple choice tests. The data were analyzed by descriptive statistic and assisted MANOVA SPSS 17. For widows. The result of the study was strengthened based on the calculation of the MANOVA test which obtained the result of the significance number of the three hypotheses 0.00 which means less than $0.05(0.00<0.05)$. The result of the study showed that there was the difference in the simultaneous SAVI learning model based on Tri Hita Karana on the students' empathy and IPA knowledge competency with a significance value of $0.00<0.05$ ). Based on the hypothesis testing it could be concluded that the SAVI learning model based on Tri Hita Karana has a positive effect on empathy attitude andstudents' IPA knowledge competency.
\end{abstract}

Key Word: IPA, SAVI, empathy attitude, THK.

\section{PENDAHULUAN}

Ketentuan mengenai pengembangan kurikulum dinyatakan dalam Undang-undang No 20 Tahun 2003 tentang Sistem Pendidikan Nasional Pasal 37 Ayat 1 menyebutkan bahwa kurikulum pada jenjang pendidikan dasar dan menengah wajib memuat beberapa mata pelajaran salah satu diantaranya adalah 
mata pelajaran Ilmu Pengetahuan Alam (IPA). Menurut Trianto (2007:99) mengemukakan bahwaIPA adalah bukan hanya tentang penguasaan kumpulan pengetahuan yang berupa fakta-fakta, atau prinsipprinsip saja, tetapi juga merupakan suatu proses penemuan. Artinya, Pendidikan IPA merupakan ilmu pengetahuan yang berhubungan dengan cara mencari tahu informasi tentang alam semesta dengan segala isinya dan usaha manusia untuk memahami alam semesta melalui pengamatan menggunakan prosedur dan dijelaskan melalui penalaran sehingga memperoleh kesimpulan. IPA merupakan ilmu pengetahuan yang mempelajari peristiwa-peristiwa yang terjadi di alam, yang erat kaitannya dengan makhluk hidup (Sudana dan Kusmariyatni, 2013).

Proses membelajarkan IPA kepada siswa khususnya pada sekolah dasar, hendak melakukan pada aktivitas yang mendukung terjadinya pemahaman tentang konsep, prinsip dalam kaitannya dengan konteks kehidupan sehari-hari. Di luar sekolah agar pembelajaran yang diberikan lebih mudah dimengerti dan bermakna bagi siswa (Susiani dkk, 2013). Cakupan IPA yang dipelajari di sekolah tidak hanya berupa kumpulan fakta, tetapi juga proses dalam memperoleh fakta yang didasarkan pada kemampuan menggunakan pengetahuan dasar IPA untuk memprediksi atau menjelaskan berbagai fenomena yang berbeda. Pendidikan IPA merupakan salah satu mata pelajaran yang digunakan sebagai alat ukur untuk mencapai tujuan pendidikan.Adapun tujuan pembelajaran IPA di sekolah dasar menurut Badan Nasional Standar Pendidikan (BNSP) salah satunya pengembangan rasa ingin tahu sikap positif dan kesadaran tentang adanya hubungan yang saling mempengaruhi antara IPA, lingkungan dan masyarakat.

Agar bisa mencapai tujuan tersebut, pembelajaran IPA di Sekolah Dasar ditentukan oleh berbagai faktor, salah satunya yang berpengaruh adalah keikutsertaan siswa secara aktif dalam pembelajaran. Keikutsertaan siswa ini akan menciptakan berbagai kompetensi dalam diri siswa. Semakin banyak persentase keterlibatan siswa dalam pembelajaran, maka suasana pembelajaran akan terasa semakin menarik. Pembelajaran yang menarik akan memberikan peluang kepada siswa untuk menuangkan ide-ide kreatifnya. Selain itu pembelajaran di Sekolah Dasar harus sesuai dengan karakteristik siswa yang masih berada dalam tahap operasonal konkret, yang belum mampu berpikir abstrak dan mempunyai karakteristik yang berbeda-beda. Hendaknya pembelajaran IPA di SD dirancang supaya sesuai dengan kebutuhan siswa SD, dengan demikian kualitas kompetensi pengetahuan IPA akan meningkat, namun dalam kenyataan proses pelaksanaan pembelajaran belum mencapai hasil yang maksimal.

Berdasarkan kenyataan pada saat melakukan wawancara, observasi, dan studi dokumen yang dilakukan pada tanggal 11-12 Januari 2019 dengan guru-guru kelas V sekolah dasar di gugus IV Kecamatan Bangli, hasil wawancara yang diperoleh yaitu 1) Dalam proses pembelajaran IPA masih banyak siswa yang kurang aktif dalam mengikuti proses pembelajaran IPA dan mudah bosan pada saat menerima pembelajaran dikelas, 2) siswa juga masih sulit memahami konsep IPA, 3) siswa kurang termotivasi dalam mengikuti pembelajaran dikelas dan sikap empati siswa masih kurang. Dilanjutkan dengan kegiatan observasi pada saat guru melaksanakan pembelajaran IPA di kelas mendapatkan hasil yaitu: 1) Pembelajaran yang dilaksanakan di kelas masih menggunakan pembelajaran yang berpusat pada guru dengan menggunakan metode ceramah. 2) Penggunaan media dan alat peraga yang digunakan dalam pembelajaran IPA kurang bervariasi sehingga membuat siswa merasa bosan. Hal itu akan berpengaruh terhadap kompetensi pengetahuan IPA yang diperoleh siswa menjadi kurang dan sikap empati siswa menjadi kurang, sehingga tujuan dari pembelajaran IPA dianggap mengalami kegagalan (Sudarma dkk, 2014).

Melengkapi data hasil wawancara dan observasi selanjutnya dilakukan studi dokumen terhadap kompetensi pengetahuan IPA kelas V Sekolah Dasar di Gugus IV Kecamatan Bangli Tahun Pelajaran 2018/2019.Berdasarkan studi dokumen yang dilakukan, diperoleh Nilai Ulangan Akhir Semester (UAS) dibawah rata-rata. Dikeahui rata-rata hasil tes IPA di SDN 1 Kubu adalah 59,41, di SDN 2 Kubu adalah 60,35, di SDN 4 Kubu adalah 59,45, di SDN 1 Kayubihi adalah 63,73, di SDN 4 Kayubihi adalah 60,83, di SDN 3 Cempaga adalah 60,27. Dilihat dari tabel 1.1 tersebut, dapat diketahui bahwa nilai rata-rata UAS IPA siswa kelas V Sekolah Dasar di Gugus IV Kecamatan Bangli berkisar antara 59,41-63,73 jika dikonversikan dengan kriteria Penilaian Acuan Patokan (PAP) Menurut Agung (2014:118) berada pada katagori rendah. Hal itu merupakan suatu masalah yang harus diatasi supaya sikap empati siswa dan kompetensi pengetahuan menjadi lebih baik.Pembelajaran yang diperlukan adalah yang melibatkan seluruh anggota tubuh siswa untuk belajar dan meningkatkan perhatian siswa dalam belajar.Salah satu alternatif model pembelajaran 
yang dapat digunakan adalah model pembelajaran SAVI berbasis Tri Hita Karana.Alasan pemilihan model pembelajaran SAVI dalam penelitian ini adalah lebih berpusat kepada siswa. Model ini lebih mengutamakan semua alat indra yang dimiliki siswa dalam kegiatan pembelajaran, sehingga membuat siswa menjadi lebih aktif dalam belajar yang menunjukkan sikap empati dan nantinya akan berpengaruh terhadap kompetensi pengetahuan IPA. Ngalimun (2016) menjelaskan pembelajaran SAVI adalah pembelajaran yang dilakukan dengan menekankan bahawa harus memanfaatkan semua alat indra yang dimiliki oleh siswa. SAVI adalah kependekan dari Somatic yang berarti gerakan tubuh belajar dengan mengalami dan melakukan.Auditory yang bermakna belajar harus dengan mendengarkan, menyimak, berbicara, presentasi, argumentasi, mengemukakan pendapat dan menanggapi.Visualization yang berarti belajar harus menggunakan indra mata melalui pengamatan, menggambar, mendemonstrasikan, membaca, menggunakan media dan alat peraga. Intellectualy yang berarti belajar harus menggunakan kempuan berpikir, belajar harus dengan konsentrasi pikiran dan berlatih menggunakannya melalui menalar, menyelidiki, mengidentifikasi, menemukan, mencipta, mengkontruksikan, memecahkan masalah dan menerapkan.

Khususnya di Bali merupakan daerah pariwisata, masih kental dengan tradisi dan budaya atau kearifan lokal.Salah satu kearifan lokal yang dikembangkan masyarakat Bali yaitu Tri Hita Karana.Dalam Tri Hita Karana terdapat tiga bagian yang merupakan unsurdari Tri Hita Karana itu sendiri yaitu, parahyangan, pawongan, dan palemahan.Dari ketiga unsur ini diajarkan untuk menghormati Tuhan, sesama manusia, dan lingkungan sekitar. Dalam konsep ini semua mahluk hidup diharuskan untuk menghormati dan menghargai sesama ciptaan Tuhan, seperti manusia, hewan, tumbuhan, dan segala mahluk hidup. Dengan diterapkannya Tri Hita Karana dalam kehidupan manusia sehari-hari, akan tercipta hubungan harmonis antara manusia dengan Tuhan, manusia dengan sesama manusia, dan manusia dengan lingkungannya. Konsep Tri Hita Karana sangat cocok diterapkan dalam proses pembelajaran IPA di sekolah dasar. Jika Model pembelajaran SAVI yang disertai dengan implementasi kearifan lokal dalam pembelajaran maka pelaksanaan pembelajaran dimana siswa diberikan kesempatan yang sama dalam mengemukakan pendapat dan tidak saling mendominasi pembicaraan, hal ini diharapkan dapat membentuk sikap empati siswa menjadi lebih baik dan meningkatkan kompetensi pengetahuan siswa.

Tri Hita Karana, berasal dari bahasa Sansekerta. Dari kata Tri yang berarti tiga, Hita berarti sejahtera/harmonis dan Karana berarti penyebab. Pengertian Tri Hita Karana adalah tiga hal pokok yang menyebabkan kesejahteraan, keharmonisan dan kemakmuran dalam hidup manusia. Konsep Tri Hita Karana yang diterapkan dalam proses pembelajaran IPA yang akan membentuk prilaku siswa menjadi lebih baik, mampu menghargai Tuhan, menghargai sesama siswa di kelas di sekolah, dan menghargai lingkungan sekitarnya.

Konsep Tri Hita Karana sudah sejalan dengan tujuan pembelajaran IPA yang mengharapkan manusia mampu memahami rahasia alam disekitar dan mampu menjaga atau melestarikan alam beserta isinya dengan menerapkan konsep Tri Hita Karana dalam pembelajaran IPA akan menciptakan suasana belajar yang kondusif dan mampu meningkatkan sikap empati siswa dan kompetensi pengetahuan siswa. Jika pembelajaran model SAVI dipadukan dengan Tri Hita Karana maka pembelajarn akan lebih menyenangkan dan bermakna yang berakibat pada peningkatan kompetensi pengetahuan IPA, karena dalam proses pembelajaran yang baik bisa menerapkan beberapa nilai-nilai kearifan lokal yang membantu siswa agar mampu meningkatkan pengetahuan, menjaga prilaku, dan sikap dalam kehidupan sehari-hari. Dengan menerapkan nilai-nilai tersebut siswa akan menjadi pribadi yang baik, mampu menjalin hubungan yang harmonis dengan Tuhan, teman dan lingkungannya.

Berdasarkan uraian di atas, maka perlu dilakukan penelitian eksperimen yang berjudul Pengaruh Model Pembelajaran SAVI berbasis Tri Hita Karana terhadap Sikap Empati dan Kompetensi Pengetahuan IPA Siswa Kelas V SD Gugus IV Kecamatan Bangli. Berdasarkan uraian diatas maka penelitian ini akan difokuskan pada pengaruh model pembelajaran SAVI berbasis Tri Hita Karana terhadap sikap empati dan kompetensi pengetahuan IPA kelas V SD di Gugus IV Kecamatan Bangli Tahun Pelajaran 2018/2019.

\section{METODE}

Tempat pelaksanan penelitian ini adalah di Gugus IV Kecamatan Banli pada rentang semester I Tahu Pelajaran 2018/2019. Peneliian ini berlangsung dari bulan April - Mei 2019. Populasi dalam penelitian ini adalah siswa kelas V SD Gugus IV Kecamatan Bangli. 
Penelitian ini merupakan jenis penelitian eksperimen semu (quasi eksperimen) karena dalam penelitian ini tidak dapat membuat kelas baru melainkan menggunakan kelas yang sudah ada pada sekolah yang dipilih. Rancangan yang digunakan dalam penelitian ini adalah nonequivalent the post-test only control group design yang secara prosedural mengikuti pola seperti yang dicontohlan pada tabel 1 . Sebagai berikut.

Tabel 1. Rancangan Penelitian

\begin{tabular}{ccc}
\hline Kelas & Treatment & Post-test \\
\hline E & $\mathrm{X}$ & 01 \\
\hline $\mathrm{K}$ & - & 02 \\
\hline
\end{tabular}

Sumber: dimodifikasi dari Sugiyono, (2014)

Teknik pengambilan sampel yang digunakan dalam penelitianini adalah teknik random sampling dengan penambilan sampel secara acak tanpa memperhatikan strata yang ada.

Tahap pertama dilakukan uji kesetaraan terhadap enam sekolah dasar tersebut. Penyertan sampel dihitung berdasarkan nilai Ulanan Akhir Semester IPA kelas V Semester I tahun pelajaran 2018/2019. Untuk menggitung kesetaran kelompok sampel dignakan rumus uji ANAVA .setelah memperoleh hasil perhiungan uji kesetaraan selanjutnya enam SD itu di random untuk menetukan kelas eksperimen dan kelas kontrok dilakukan dengan tekik undian.Setela dilakukan penundian didapatkan kelas V dari SDN 2 Kubu sebagai kelas eksperimen.Selanjutnya didapatkan kelas V dari SDN 3 Cempaga sebagai kelas kontrol. Kelas eksperimen diberikan perlakuan dengan menerapkan model pembelajaran SAVI berbasis Tri Hita Karana dan kelas kontrol dengan pembelajaran yan berangsung seperi biasanya atau tidak mendapatkan perlakukan dengan model pembelajaran SAVI berbasis Tri Hita Karana.

Dalam penelitian ini perlakuan diberikan pada kelas eksperimen dengan menggunakan model pembelajaran SAVI berbasis Tri Hita Karana. Sedangkan pada kelas control tidak diberikan perlakuan khusus artinya tidak digunakan model pembelajaran SAVI berbasis Tri ita Karana, tetapi pembelajaran yang diterapkan di kelas kontrol adalah pembelajaran yang telah bisa guru terapkan dalam proses pembelajaran. Setelah perlakuan baik kelas eksperimen maupun kontrol diberikan post-test untuk mengetahui kompetensipengetahuan dan sikap empati masing-masing kelompok. Karena dalam penelitian ini mengontrol siap empati maka diukur menggunakan kuesioner yang diberikan setelah pelaksanaan pembelajaran. Untuk menetahi sikap empati siswa dimasingmasing kelompok.

Data yang diumpulkan dalam penelitian ini adalah skor kompetensi pengetahuan IPA dan sikap empati siswa kelas V SD. Metode pengumpulan data yang dignakan dalam penelitian ini adalah metode es dan instrumen kuesioner.

Instrumen pengumpulan data yang digunakan dalam penelitian ini adalah berupa tes objektif dan kuesioner sikap empati.Soal objektif yang digunakan terdiri ari 30 butir soal.Sedangkan kuesioner sikap empati terdiri dari 25 butir soal.Untuk menentukan butir soal instrumen tersebut layak untuk diberikan terhadap kelmpok sampel terlebih dahulu dilakukan validasi instrumen. Validasi tes kompetensi pengetahuan IPA meliputi: validasi isi menggunakan rumus Gregory validasi butir tes menggunakan rumus korelasi point biserial, reliabilitas tes menggunakan KR-20, daya beda tes dan ingkat kesukaran. Sedankan uji coba untuk kuesioner sikap empati meliputi: validasi isi menggunakan rumus Gregory validasi butir menggnakan rumus korelasi product moment, dan reliabilitas KR-20.

Analisis data yang digunakan dalam penelitian ini mengunakan MONOVA. Sebelum dilakukan uji hipotesis, terlebih dahulu dilakukan uji prasyarat analisis yang meliputi uji normalitas sebaran data, uji homogenitas varian, dan ujikorelasi antar dua variabel.Seluruh pengujian yang dilakukan menggunakan bantuan SPSS 17.0 for windows.

\section{HASIL DAN PEMBAHASAN} HASIL

Hal yang dibandingkan dalam peneliian ini, adalah secara simultan, sikap empati dan kompetensi pengeahuan IPA yang dibelajarkan dengan model pembelajaran SAVI berbasis Tri Hita Karana dengan pembelajaran konvensional. Rangkuman hasil analis statistik disajikan pada tabel 2 sebagai berikut. 
Tabel 2. Rangkuman Statistik Deskriptif Variabel Penelitian

\begin{tabular}{lllll}
\hline & Variabel & & A1 & \multicolumn{2}{c}{ A2 } \\
\hline Statistik & Y1 & Y2 & Y1 & Y2 \\
$\mathrm{N}$ & 23 & 23 & 22 & 22 \\
Mean & 98,83 & 18,04 & 71,55 & 16,18 \\
Median & 99,7 & 18,3 & 71,5 & 16,5 \\
Modus & 99,5 & 19,5 & 69 & 17,5 \\
Standar Deviasi & 6,71 & 2,75 & 6,51 & 2,61 \\
Minimum & 87 & 13 & 62 & 11 \\
Maksimum & 111 & 22 & 85 & 20 \\
\hline
\end{tabular}

Setelah didapatkan hasil analisis deskriftif data maka dilanjukan dengan uji prasyarat yang dilakukan dengan uji normalitas sebaran data, uji homogenitas, dan uji korelasi antar variabel terikat.

Pengujian normalitas sebaran data menggunakan teknik analisis Kolmogorov-Smirnov dan Shapiro Wilk berbantuan SPSS 17 for Windows pada taraf signifikan 0,05, didapatkan hasil seberi table 03 sebagai berikut.

Tabel 3. Rekapitulasi Hasil Uji Normalitas

\begin{tabular}{llrrrrrr}
\hline Variabel & & Statistic & Df & \multicolumn{1}{c}{ Sig. } & Statistic & df & \multicolumn{2}{c}{ Sig. } \\
\hline SikapEmpati & Eksperimen & .089 & 23 & $.200^{*}$ & .971 & 23 & .720 \\
& Kontrol & .107 & 22 & $.200^{*}$ & .963 & 22 & .557 \\
KompetensiPengetahuan & Eksperimen & .114 & 23 & $.200^{*}$ & .951 & 23 & .309 \\
IPA & Kontrol & .123 & 22 & $.200^{*}$ & .958 & 22 & .445 \\
\hline
\end{tabular}

Berdasarkan hasil perhitungan post test kelompok eksperimen dan kontrol dengan menggunakan SPSS 17.0, for windows dari out put analisis menunjukkan nilai kolmogrov Smirnov (a) sikap empati adalah 0,200 dan 0.200 sedangkan nilai dari kompetensi pengetahuan adalah 0,200 dan 0,200. Oleh karena itu nilai probabilitas kedua nilai signifikan $>0,05$, maka data hasil post-test kelompok eksperimen dan kontrol berdistribusi normal.Setelah diketahui seluruh sebaran data berdistribusi normal, maka dilanjutkan dengan ui homogenitas varians. Untuk menguji homogenitas varians menggunakan uji Levene's Test of Equality of Error varians pada taraf sinifikansi 0,05 berbantuan SPSS 17 for Windows seperti tabel 4 sebagai berikut.

Tabel 4. Rekapitulasi Hasil Uji Homogenitas Varians

\begin{tabular}{lllll}
\hline & $\begin{array}{l}\text { Levence } \\
\text { Statistik }\end{array}$ & df1 & df1 & Sig. \\
\hline Sikap Empati & .001 & 1 & 43 & .975 \\
$\begin{array}{l}\text { Kompetensi } \\
\text { Pengetahuan }\end{array}$ & .090 & 1 & & \\
\hline
\end{tabular}

Uji homogenitas varians menggunakan bantuan program SPSS-17.0 for windows pada taraf signifikan 0,05. Uji homognitas menggunakan Test of Homogeneity of Variance menghasilkan angka signifikan sikap empati sebesar 0,975 dan kompetensi pengetahuan sebesar 0,766. Hasil dapat ditampilkan pada tabel 04.Hasil analisis menunjukan bahwa angka signifikan yang dihasilkan secara terpisah lebih besar dari 0,05. Dengan demikian dapat disimpulkan bahwa variabel sikap empati dan kompetensi pengetahuan 
adalah homogen. Setelah didapatkan hasil analisis prasyarat, selanjutnya dilakukan uji hipotesis dengan menggunakan uji ANAVA dan MANOVA. Uji ANAVA digunakan untuk menguji hipotesis I dan II sedangkan uji MANOVA digunakan untuk menguji hipotesis III.

Pengujian hipotesis I menggunakan bantuan SPSS-17.0 for windows. Kriteria pengujiannya adalah apabila nilai signifikansi lebih kecil dari 0.05 maka H0 ditolak H1 diterima. Dengan kata lain terdapat pengaruh model pembelajaran SAVI berbasis Tri Hita Karana terhadap sikap empati kelas V SD di Gugus IV Kecamatan Bangli tahun pelajaran 2018/2019. Berikut hasil analisi hipotesi I menggunakan uji ANAVA berbantuan SPSS-17.0 for windowspada tabel 5 sebagai berikut.

Tabel 5. Hasil Uji Hipotesis 1

\begin{tabular}{|c|c|c|c|c|c|}
\hline & Sum of Squares & $\mathrm{df}$ & Mean Square & $\mathrm{F}$ & Sig. \\
\hline Between Groups & 8368.486 & 1 & 8368.486 & 190.924 & .000 \\
\hline Within Groups & 1884.759 & 43 & 43.832 & & \\
\hline Total & 10253.244 & 44 & & & \\
\hline
\end{tabular}

Berdasarkan tabel Uji ANOVA di atas, didapatkan nilai signifikan sikap empati pada kolom Sig. sebesar 0.000 dan lebih kecil dari 0.05.sehingga dapat disimpulkan bahwa hipotesis nol $\left(\mathrm{H}_{0}\right)$ ditolak dan hipotesis alternative $\left(\mathrm{H}_{\mathrm{a}}\right)$ diterima. Hal ini berarti bahwa terdapat pengaruh Model Pembelajaran SAVI berbasis Tri Hita Karana terhadap Sikap Empati pada siswa kelas V SD Gugus IV Kecamatan Bangli Tahun Pelajaran 2018/2019.

Pengujian hipotesis I menggunakan bantuan SPSS-17.0 for windows. Kriteria pengujiannya adalah apabila nilai signifikansi lebih kecil dari 0.05 maka H0 ditolak H1 diterima. Dengan kata lain terdapat pengaruh model pembelajaran SAVI berbasis Tri Hita Karana terhadap sikap empati kelas V SD di Gugus IV Kecamatan Bangli tahun pelajaran 2018/2019. Berikut hasil analisi hipotesi I menggunakan uji ANAVA berbantuan SPSS-17.0 for windowspada tabel 6 sebagai berikut.

Tabel 6. Hasil Uji Hipotesis 2

\begin{tabular}{lrcccc}
\hline & Sum of Squares & df & Mean Square & F & Sig. \\
\hline Between Groups & 38.971 & 1 & 38.971 & 5.402 & .000 \\
Within Groups & 310.229 & 43 & 7.215 & & \\
Total & 349.200 & 44 & & & \\
\hline
\end{tabular}

Berdasarkan hasil analisis uji anava yang dilakukan pada table ANOVA di atas, didapatkan nilai signifikan kompetensi pengetahuan pada kolom Sig. sebesar 0.000 dan lebih kecil dari 0.05.sehingga dapat disimpulkan bahwa hipotesis nol $\left(\mathrm{H}_{0}\right)$ ditolak dan hipotesis alternative $\left(\mathrm{H}_{\mathrm{a}}\right)$ diterima. Hal ini berarti bahwa terdapat pengaruh Model Pembelajaran SAVI berbasis Tri Hita Karana terhadap Kompetensi Pengetahuan IPA pada siswa kelas V SD Gugus IV Kecamatan Bangli Tahun Pelajaran 2018/2019.

Pengujian hipotesis ini dilakukan dengan uji MANOVA, dengan analisi Pillai's Treace, Wilks'Lambda, Hotelling's Trice, dan Roy's Larget Rootdilakukan dengan bantuan SPSS-17.0 for windows. Kriteria pengujiannya adalah apabila nilai signifikansi (F) lebih kecil dai 0.05 maka H0 ditolak. Dengan kata lain. Secara simultan terdapat pengaruh yang signifikan model pembelajaran SAVI berbasis Tri Hita Karana terhadap sikap empati dan kompetensi pengetahuan IPA kelas V SD di Gugus IV Kecamatan Bangli tahun pelajaran 2018/2019. Berikut hasil analisis hipotesis III menggunakan MANOVA berbantuan SPSS-17.0 for windowspada tabel 07 sebagai berikut. 
Tabel 7. Hasil Hipotesis 3 menggunakan MANOVA

\begin{tabular}{llrrrrr}
\hline Effect & & \multicolumn{1}{c}{ Value } & \multicolumn{1}{c}{ F } & Hypothesis df & \multicolumn{1}{c}{ Error df } & \multicolumn{1}{l}{ Sig. } \\
\hline Intercept & Pillai's Trace & .995 & $4576.116^{\mathrm{a}}$ & 2.000 & 42.000 & .000 \\
& Wilks' Lambda & .005 & $4576.116^{\mathrm{a}}$ & 2.000 & 42.000 & .000 \\
& Hotelling's Trace & 217.910 & $4576.116^{\mathrm{a}}$ & 2.000 & 42.000 & .000 \\
& Roy's Largest Root & 217.910 & $4576.116^{\mathrm{a}}$ & 2.000 & 42.000 & .000 \\
$\mathrm{Y}$ & .821 & $96.307^{\mathrm{a}}$ & 2.000 & 42.000 & .000 \\
& Pillai's Trace & .179 & $96.307^{\mathrm{a}}$ & 2.000 & 42.000 & .000 \\
& Wilks' Lambda & 4.586 & $96.307^{\mathrm{a}}$ & 2.000 & 42.000 & .000 \\
& Hotelling's Trace & 4.586 & $96.307^{\mathrm{a}}$ & 2.000 & 42.000 & .000 \\
\hline
\end{tabular}

Berdasarkan tabel multivariate Test di atas, didapatkan nilai signifikan Pillai's Treace, Wilks'Lambda, Hotelling's Trice, dan Roy's Larget Root sebesar 0.000 dan lebih kecil dari 0,05. Sehingga dapat disimpulkan bahwa hipotesis nol $\left(\mathrm{H}_{0}\right)$ ditolak dan hipotesis alternative $\left(\mathrm{H}_{\mathrm{a}}\right)$ diterima.Jadi terdapat pengaruh secara simultan pengaruh Model Pembelajaran SAVI Berbasis Tri Hita Karana terhadap Sikap Empati dan Kompetensi Pengetahuan IPA siswa kelas V SD Gugus IV Kecamatan Bangli Tahun Pelajaran 2018/2019.

\section{PEMBAHASAN}

Penelitian ini menemukan bahwa terdapat pengaruh yang signifikan model pembelajran SAVI berbasis Tri Hita Karana terhadap Sikap Empati siswa. Untuk mengetahui besarnya pengaruh model pembelajaran SAVI berbasis Tri Hita Karana dan pembelajaran konvensional dapat dilihat dari nilai ratarata kompetensi pengetahuan IPA antara kedua kelompok. Rata-rata nilai Sikap Empati siswa yang mengikuti model pembelajaran SAVI berbasis Tri Hita Karana yaitu 98,83. Sedangkan nilai rata-rata Sikap Empati siswa yang mengikuti pembelajaran konvensional sebesar 71,55. Hal ini berarti, rata-rata skor kelompok eksperimen lebih besar dari rata-rata skor kelompok eksperimen $(98,83>71,55)$.Ini berarti model pembelajaran SAVI berbasis Tri Hita Karana berpengaruh positif terhadap sikap empati siswa.

Berdasarkan penelitian yang telah dilakukan dan diperkuat oleh pendapat diatas, maka model pembelajaran SAVI berbasis Tri Hita Karana berpengaruh signifikan terhadap sikap empati kelas V SD di Gugus IV Kecamatan Bangli Tahun Pelajaran 2018/2019.

Perbedaan sikap empati antara siswa yang mengikuti model pembelajaran SAVI berbasis Tri Hita Karana dengan siswa siswa yang tidak mengikuti model pembelajaran SAVI berbasis Tri Hita Karana yang disebabkanoleh pelaksanaan pembelajaran dengan model SAVI berbasis Tri Hita Karana memberikan wawasan lebih luas kepada siswa untuk memiliki rasa peduli terhadap lingkungan tempat mereka belajar.

Penelitian ini menemukan bahwa terdapat pengaruh yang signifikan model pembelajaran SAVI berbasis Tri Hita Karana terhadap kompetensi pengetahuan IPA siswa. Untuk mengetahui besarnya pengaruh model pembelajaran SAVI berbasis Tri Hita Karana dan pembelajaran konvensional dapat dilihat dari nilai rata-rata kompetensi pengetahuan IPA antara kedua kelompok. Rata-rata nilai kompetensi pengetahuan IPA siswa yang mengikuti model pembelajaran SAVI berbasis Tri Hita Karana yaitu 18,04. Sedangkan rata-rata nilai kompetensi pengetahuan IPA siswa yang mengikuti pembelajaran konvensional yaitu 16,18. Hal ini berarti rata-rata skor kelompok eksperimen lebih besar dari rata-rata skor kelompok kontrol $(18,04>16,18)$. Ini berarti model pembelajaran SAVI berbasis Tri

Hita Karana berpengaruh positif terhadap kompetensi pengetahuan IPA.

Berdasarkan hasil analisis dan temuan lain yang sesuai dengan penelitian ini, dapat disintesiskan bahawa model pembelajaran SAVIberbasis Tri Hita Karana berpengaruh terhadap kompetensi pengetahuan IPA kelas V SD Gugus IV Kecamatan Bangli Tahun Pelajaran 2018/2019.

Kompetensi pengetahuan IPA siswa yang tergolong tinggi pada kelas eksperimen dengan model pembelajaran SAVI berbasis Tri Hita Karana dipengaruhi oleh beberapa faktor. Pertama, model 
pembelajaran SAVI berbasis Tri Hita Karana memberikan pemahaman kepada siswa dalam mengenal, memahami dan menerapkan berbagai materi/informasi melalui belajar aktif dan interaksi dengan lingkungan. Model pembelajaran SAVI mengandung prinsip belajar berdasarkan aktivitas yang berarti bergerak aktif secara fisik saat pembelajaran berlangsung, dengan memanfaatkan indra sebanyak mungkin dan membuat seluruh tubuh dan pikiran terlibat aktif dalam proses belajar.

Faktor kedua, pembelajaran menggunakan model pembelajaran SAVI berbasis Tri Hita Karana, siswa bisa belajar memahami dan menerapkan nilai-nilai penting konsep Tri Hita Karana dalam belajar. Tri Hita Karana akan mendorong siswa untuk belajar bermakna melalui interaksi-interaksi yang terjadi saat pembelajaran IPA berlangsung. Bagian Tri Hita Karana yang pertama Parhyangan, dengan penerapan bagian Tri Hita Karana ini siswa akan terbiasa untuk berdoa sebelum dan sesudah pembelajaran berlangsung, yang kedua yaitu Pawongan siswa akan terbiasa untuk saling menghargai pendapat dan perbedaan dengan temannya, sehingga suasana kelas menjadi harmonis, dan yang ketiga Palemahan, dengan penerapan bagian Tri Hita Karana yang terakhir ini siswa akan terbiasa untuk memanfaatkan lingkungannya dengan bijak dan menjaga lingkungannya supaya tetap asri dan lestari.

Berdasarkan hasil analisis dan temuan lain yang sesuai dengan penelitian ini, dapat disintesiskan bahawa model pembelajaran SAVIberbasis Tri Hita Karana berpengaruh terhadap kompetensi pengetahuan IPA kelas V SD Gugus IV Kecamatan Bangli Tahun Pelajaran 2018/2019.

Hasil analisis data menunjukkan secara simultan terdapat pengaruh yang signifikan model pembelajaran SAVI berbasis Tri Hita Karana terhadap sikap empati dan kompetensi pengetahuan IPA siswa. Hal ini dapat dilihat dari hasil uji MANOVA yang telah dilakukan.

Berdasarkan hasil uji hipotesis ketiga dalam penelitian ini peroleh analisis, nilai $\mathrm{F}=96.307$ dan signifikan hitung untuk Pillai's Treace, Wilks'Lambda, Hotelling's Trice, dan Roy's Larget Root yang seluruhnya memiliki signifikansi 0,00 dan lebih kecil dari 0,05, makan hipotesis ketiga diterima yaitu secara simultan terdapat pengaruh yang signifikan model pembelajaran SAVI berbasis Tri Hita Karana terhadap sikap empati dan kompetensi pengetahuan IPA kelas V SD di Gugus IV Kecamatan Bangli.

Dari hasil analisis yang di lakukan dan dibuktikan melalui pengamatan langsung dalam pembelajaran bahwa model pembelajaran SAVI berbasis Tri Hita Karana merupakan model pembelajaran yang menekankan cara belajar melalui aktivitas yang menuntut siswa supaya memanfaatkan seluruh indra yang dimiliki dan pikirannya dalam proses pembelajaran. Pembelajaran dengan menggunakan model pembelajaran SAVI akan membuat pembelajaran manjadi lebih bermakna karena siswa terlibat aktif dan memberikan pengalaman langsung dalam proses pembelajaran. Sejalan dengan pendapat Ngalimun (2016) menjelaskan bahwa model pembelajaran SAVI adalah pembelajaran yang menekankan untuk memanfaatkan semua alat indra yang dimiliki oleh siswa. SAVI adalah kependekan dari Somatic yang berarti gerakan tubuh belajar dengan mengalami dan melakukan. Auditory yang bermakna belajar harus dengan mendengarkan, menyimak, berbicara, presentasi, argumentasi, mengemukakan pendapat dan menanggapi. Visualization yang berarti belajar harus menggunakan indra mata melalui pengamatan, menggambar, mendemonstrasikan, membaca, menggunakan media dan alat peraga. Intellectualy yang berarti belajar harus menggunakan kempuan berpikir, belajar harus dengan konsentrasi pikiran dan berlatih menggunakannya melalui

menalar, menyelidiki, mengidentifikasi, menemukan, mencipta, mengkontruksikan, memecahkan masalah dan menerapkan. Meier (2001) mengemukakan bahwa pembelajaran tidak otomatis meningkat dengan menyuruh seseorang berdiri kesana kemari, tetapi dengan cara menggabungkan gerakan fisik dengan aktivitas intelektual dan penggunaan semua indra dapat berpengaruh sangat besar terhadap pembelajaran.

Partadjaja (2009) menyatakan bahwa Tri Hita Karana sebagai konsep yang bersifat universal dan merupakan landasan hidup menuju kebahagiaan dan keharmonisan lahir batin. Tri Hita Karana sangat cocok diterapkan dalam proses pendidikan karena konsep ini juga akan menciptakan proses pembentukan karakter atau sikap siswa yang baik. Banyak proses pembelajaran yang positif akan didapatkan oleh siswa salah satunya meningkatkan sikap empati, kompetensi pengetahuan, terciptanya pembelajaran yang lebih harmois di kelas, seperti siswa lebih menghormai seluruh gurunya dan siswa juga menjaga lingkungan kelasnya.Teori tersebut didukung oleh penelitian yang dilakukan oleh Mahendra (2017) yang mendapatkan hasil penelitian yang menunjukkan bahwa terdapat perbedaan hasil belajar IPA antara kelompok siswa yang dibelajarkan dengan menggunakan model pembelajaran SAVI dan kelompok siswa yang dibelajarkan 
bukan dengan model pembelajaran SAVI. Hal ini dibuktikan dari Data hasil belajar IPA dikumpulkan menggunakan tes objektif. Data dianalisis dengan menggunakan uji-t separated varians. Hal itu ditunjukkan oleh nilai $t_{\text {hitung }}(7,07)>t_{\text {tabel }}(2,01)$ yang diuji pada taraf signifikansi $5 \%$ dengan derajat kebebasan sebesar 41. Dan sejalan dengan penelitian yang dilakukan oleh Juniarta (2014), yaitu hasil penelitiannya menunjukkan bahwa: terdapat perbedaan yang signifikan antara hasil belajar kelompok siswa yang belajar dengan menggunakan pendekatan SAVI dan hasil belajar kelompok siswa yang belajar dengan model pembelajaran konvensional ( $t_{\text {hitung }}=3,41>t_{\text {tabel }}=2,021 ; d b=40$ ). Hal ini berarti bahwa hasil belajar siswa yang dibelakarkan dengan pendekatan $S A V I$ lebih baik dari pada hasil belajar siswa yang dibelajarkan dengan model konvensional.

Berdasarkan hasil analisis dan temuan lain yang sesuai dengan penelitian ini, dapat disimpulkan bahwa model pembelajaran SAVI berbasis Tri Hita Karana berpengaruh secara simultan terhadap sikap empati dan kompetensi pengetahuan IPA kelas V SD di Gugus IV Kecamatan Bangli Tahun Pelajaran 2018/2019. Hal ini disebabkan oleh model pembelajaran SAVI yang mengandung prinsip belajar berdasarkan aktivitas yang berarti bergerak aktif secara fisik saat belajar, dengan memanfaatkan indra dan membuat seluruh tubuh dan pikiran terlibat dalam proses belajar.

\section{SIMPULAN DAN SARAN}

Berdasarkan hasil penelitian yang telah dipaparkan dapat disimpulkan sebagai berikut: (1) terdapat pengaruh Model Pembelajaran SAVI berbasis Tri Hita Karana terhadap Sikap Empati pada siswa kelas V SD Gugus IV Kecamatan Bangli Tahun Pelajaran 2018/2019. (2) terdapat pengaruh Model Pembelajaran SAVI berbasis Tri Hita Karana terhadap Kompetensi Pengetahuan IPA pada siswakelas V SD Gugus IV Kecamatan Bangli Tahun Pelajaran 2018/2019. (3) Secara simultan terdapat pengaruh yang signifikan Model Pembelajaran SAVI Berbasis Tri Hita Karana terhadap Sikap Empati dan Kompetensi Pengetahuan IPA siswa kelas V SD Gugus IV Kecamatan Bangli Tahun Pelajaran 2018/2019. Berdasarkan hasil penelitian dan pembahasan, didapatkan nilai signifikan Pillai's Treace, Wilks'Lambda, Hotelling's Trice, dan Roy's Larget Root sebesar 0.000 dan lebih kecil dari 0,05.

Berdasarkan hasil penelitian yang sudah dipaparkan, maka saran yang dapat ditunjukkan kepada pihak-pihak seagai berikut: (1) Kepada Siswa-siswa di Sekolah Dasar agar lebih aktif dalam mengikuti proses pembelajaran IPA dan terus mengembangkan pemahaman IPA dengan membangun sendiri

pengetahuan tersebut melalui pengalaman, (2) Kepada Guru-guru IPA Sekolah Dasa ragar lebih meningkatkan wawasan dan inovatif dalam memilih model pembelajaran dan media pembelajaran yang akan diterapkan pada proses pembelajaran. Sehingga pembelajaran lebih efektif dan menarik, tidak monoton, serta dapat meningkatkan sikap empati dan kompetensi pengetahuan IPA siswa, (3) Kepala Sekolah disarankan agar dapat menciptakan kondisi yang mampu mendorong para guru untuk mencoba menerapkan Model Pembelajaran SAVI berbasis Tri Hita Karana dalam pembelajaran IPA khususnya dan mata pelajaran lain pada umumnya dalam upaya meningkatkan sikap empati dan kompetensi pengetahuan IPA siswa. Sehingga tujuan sekolah bisa tercapai dan dapat meningkatkan prestasi sekolah, (4) Kepada Peneliti lain disarankan melakukan penelitian hendaknya dapat menggunakan model, metode, maupun strategi pembelajaran yang sesuai dengan permasalahan yang ditemukan dalam pembelajarn di kelas. Selain itu, kepada peneliti lain yang berminat untuk mengadakan penelitian lebih lanjut tentang Model Pembelajaran SAVI berbasis Tri Hita Karana dapat menjadikan hasil penelitian ini sebagai salah satu referensi dalam bidang ilmu lainnya. Dan penelitian ini juga bisa dijadikan sebagai bahan pertimbangan untuk perbaikan dan penyempurnaan penelitian yang akan dilaksanakan.

\section{DAFTAR PUSTAKA}

Agung, AA. Gede. 2014. Metodelogi Penelitian Pendidikan. Singaraja: Universitas Pendidikan Ganesha. Astami Wira Ni Md. 2016. "Penerapan Inkuiri Terbimbing berbasis Tri Hita Karana Dapat Meningkatkan Sikap Sosial dan Kompetensi Pengetahuan IPS". E-journal Pendidikan Guru Sekolah Dasar Universitas Pendidikan Ganesha. Vol. 4.

Atmaja Md Dony Marta. 2017. "Pengaruh Model Pembelajaran SAVI terhadap Nilai Karakter PKn Siswa kelas V SD”. E-journal Pendidikan Guru Sekolah Dasar Universitas Pendidikan Ganesha. Vol. 5

BSNP.2011. Panduan Penyusunan Kurikulum Tingkat Satuan Pendidikan dasar dan Menengah. Jakarta: BSNP 
Depdiknas. 2003. Undang-Undang No. 20 Tahun 2003 tentang Sistem Pendidikan Nasional. Jakarta: Depdiknas.

Meier, Dave.2001.The Accelerated Learning (Handbook).Bandung: Mizan Pustaka.

Mahendra, I Wayan Alit.2017."Pengaruh Model Pembelajaran SAVI Berbantuan Permainan Terhadap Hasil Belajar IPA Kelas V SD”. E-journal mimbar PGSD Universitas Pendidikan Gaenesha.Vol 5, no 2.

Ngalimun. 2016. Stategi dan Model Pembelajaran. Yogyakarta: Aswaja Pressindo.

Sudarma, I Nyoman.dkk. 2014. "Pengaruh Model Pembelajaran Berbasis Masalah Terhadap Aktivitas dan Hasil Belajar IPA Siswa kelas V SD Gugus II Kecamatan Kuta Tahun Pelajaran 2013/2014”. eJournal Pascasarjana Universitas Pendidikan Ganesha Program Studi Pendidikan Dasar. Volume 4.

Sugiyono, 2014.Metode Penelitian Kualitatif dan R\&D. Bandung: CV. Alfabeta.

Susiani, Ketut. Dkk. 2013. "Pengaruh Model Pembelajaran Quantum Terhadap Kecerdasan Sosio Emosional dan Prestasi Belajar IPA Siswa kelas V SD di Banyuning". e-Journal Pascasarjana Universitas Pendidikan Ganesha Program Studi Pendidikan Dasar, Volume 2 (hlm. 1-10).

Trianto. 2007. Model Pembelajaran Terpau dalam Teori dan Praktek. Jakarta: Prestasi Pusaka

Weda Gustana I Wayan. 2016. " Pengaruh Model Pembelajaran SAVI bermuatan Tri Hita Karana terhadap Hasil Belajar IPS siswa kelas IV". E-journal Pendidikan Guru Sekolah Dasar Universitas Pendidikan Ganesha Vol. 4.

Widnyana I Gede. 2017. “Pengaruh Model Pembelajaran Role Playing Berbasi Tri Hita Karana Terhadap Kompetensi Pengetahuan IPS Siswa kelas IV SD Gugus Untung Surapati Kecamatan Denpasar Timur Tahun Pelajaran 2016/2017". e-jounal Pendidikan Guru Sekolah Dasar Universitas Pendidikan Ganseha, Volume 5. 